\title{
МЕЛОДРАМА ІВАНА ГУШАЛЕВИЧА «ПІДГРЯНИ» З МУЗИКОЮ МИХАЙЛА ВЕРБИЦЬКОГО В ПОСТАВАХ ТЕАТРАЛЬНИХ ТРУП МИХАЙЛА СТАРИЦЬКОГО ТА МАРКА КРОПИВНИЦЬКОГО (1884-1900)
}

У статті вперше в українському театрознавстві розглянуто поставу «Підгіряни» І. Гушалевича на музику М. Вербицького у трупах М. Старицького та М. Кропивницького (1884-1900 рр.). Залучено цілий ряд рецензій російськомовної періодики того часу та Галицьку пресу, використано публікаиії, листи, музейні та архівні матеріли.

Ключові слова: вистава «Підгіряни» І. Гушалевича, музика М. Вербицького, театральна діяльність М. Старицького, М. Кропивницького останньої чверті ХІХ ст., М. Заньковецька, Є. Зарницька.

В статье впервые в украинском театроведении рассмотрена постановка пьесы «Подгоряне» И. Гушалевича на музыку М. Вербиикого в труппах М. Стариикого и М. Кропивнииякого (1884-1900 гz.). Использован цельй ряд рецензий русской периодики того времени и Галицкую прессу, а также публикации, письма, музейные и архивные материальы.

Ключевые слова: спектакль «Подгоряне» И. Гушалевича, музыка М. Вербицкого, театральная деятельность М. Старицкого, М. Кропивницкого последней четверти ХІХ столетия, М. Заньковецкая, Е. Зарниикая.

For the first time in the Ukrainian theater studies, this article discusses the I. Hushalevych's and M. Verbitskyi's (music) play "Pidhiriany» productions by the Starytskyi and Kropyvnytskyi companies in 18841900. The author utilizes contemporary periodical reviews and Galician press, publications, letters, museum, and archival collections.

Key words: play "Pidhiriany», I. Hushalevych, M. Verbytskyi, Starytskyi and Kropyvnytskyi productions, last quarter of the nineteenth century, Maria Zankovetska, Eufrosinia Zarnytska.

У Галичині, що входила до складу Австро-Угорської імперії, 29 березня 1864 р. у Львові розпочав свою діяльність Руський (український) народний театр Товариства «Руська бесіда». За перше десятиліття свого існування театр пережив не лише хвилини творчих підйомів, а й миті глибоких криз - змінювалися режисери, актори, часті мандри містечками і селами Галичини - усе це не сприяло творчій стабільності.

Коли у січні 1874 р., уклавши угоду з Виділом Товариства «Руська Бесіда», народний театр очолила артистка Теофілія Романович (Рожанська) справи змінилися на краще. Ось як оцінив їі діяльність Степан Чарнецький у своєму «Нарисі історії українського театру в Галичині»: «Дирекція Романовички тривала до кінця 1880 р. й записалася як краща доба в історії розвитку театру <..> Вона подбала передовсім, щоб скомплектувати добрий театральний гурт <..> За порадою одного
3 виділових [керівників - Б. К.] «Бесіди» д-р Володимира Ганкевича, що познайомився був з Марком Кропивницьким в часі свого побуту в Одесі, Романовичка запросила до свого гурту “батька" українського театру, що після львівського сезону (11.III - 11. IV. 1875), з переїздом театру до Тернополя приїхав туди з України (йому було тоді 34 роки)» [23, 83-84]. Чи не найкраще дослідив працю актора і режисера М. Кропивницького в Руському народному театрі професор Львівського університету академік М. Возняк у статті «В єднанні $з$ народом Наддніпрянщини» [4, 144-169]. Цікавою $є$ також розвідка К. Осиповича «Марко Лукич Кропивницький в Галичині 1875 р.» [15], що друкувалася впродовж вересня-жовтня 1935 р. в галицькій газеті «Новий час».

У своїй «Автобіографії (за 65 літ)» Марко Кропивницький коротко згадує про перебування в трупі Т. Романович, говорячи, зокрема, про 
репертуар театру: «Із всього тамтешнього репертуару я дивився з задоволенням тільки "Підгоряни”. Бачив твори і Воробкевича "Гнат Приблуда" (сентиментальна водиця на 5 дій), “Румпель Майор", цілком підробка під німецьку оперетку... Потім бачив "Гальку" [С. Монюшка - Б. К.], а далі якісь такі неможливі твори як “Фальшиєри банкноти" і щось цьому подібне» $[7,71]$. Саме 3 іменем М.Кропивницького буде пов'язане довголітнє сценічне життя мелодрами I. Гушалевича «Підгіряни» 3 музикою М. Вербицького на сценах Наддніпрянської України, Росії, Польщі, Білорусі та Литви. Власне це і становить суть нашого дослідження.

Наскільки музика та пісні М. Вербицького до вистави «Підгіряни» I. Гушалевича припали до душі М. Кропивницькому, свідчить описаний в «Автобіографії» епізод, пов’ язаний з 1876 р., коли 3'явився Емський указ, що забороняв друк і виконання на сцені творів українською мовою. «В день заборони, - пише М. Кропивницький, йшла драма “Дай серцю волю...” і дивертисмент (у перерві між заміною декорацій на сцені перед завісою актори читали вірші, виконували вокальні твори - Б. К.). В дивертисменті я співав відому пісню із "Підгорян" "Поле моє, поле", але не доспівав іiі і розплакався. Дружина моя боялася, щоб я не заподіяв чого з собою і мусила слідкувати за мною» [7, 72]. Прекрасна мелодія Михайла Вербицького і слова пісні про рідне поле емоційно посилили в його душі біль від заборони рідного слова і театру, що потім у саду він гірко плакав i «бився головою об дуба» [7, 72].

Боротьба за українське слово і театр тривала понад 5 літ. I коли 1880 р. почала скресати крига заборони, і в таких містах, як Полтава, Слисаветград, Херсон, Одеса на прохання антрепренерів російських труп через поганий фінансовий стан театрів було дозволено грати вистави й українською мовою, то листи-прохання про дозвіл почали надходити й з інших міст. 3 огляду на це у серпні 1881 р. у Петербурзі скликано «Особливу нараду» щодо цензури та окремих пунктів Емського указу, зокрема, пункту третього, де йшлося про театральні вистави українською мовою та тексти до вокальних творів. У новому рішенні мовилося: «Пункт третій роз'яснити в тому сенсі, що драматичні п'єси, сцени і куплети малоруським наріччям, які дозволені до вистав за попередніх часів драматичною цензурою і які можуть бути знову дозволеними Головним управлінням у справах друку, можуть виконуватись на сцені, однак з особливого на те кожного разу дозволу генерал-гу- бернаторів, а в місцевостях не підпорядкованих генерал-губернаторам, - 3 дозволу губернаторів $<$..> Зовсім заборонити улаштування спеціально малоросійського театру i формування труп для виконання п'єс і сцен виключно на малоруському наріччі» [18, 372].

У сезоні 1881-1882 pp. М. Кропивницький виступав у російській трупі антрепренера Григорія Ашкаренка і намовив його й собі попросити дозволу грати вистави українською мовою. «В грудні 1881 р., - записав у своїй «Автобіографiї...» М. Кропивницький, — ми здобули від міністра Лорис-Мелікова дозвіл на виконання укр. [аїнських] п’єс. Що діялося в Кременчуку, коли наліпили афішу "Наталка Полтавка" i "Кум-мірошник”, трудно переказать» [7, 73].

У вересні 1882 р. М. Кропивницький формує власну трупу. До неї він запрошує деяких акторів 3 колишньої трупи Ашкаренка та обдарованих аматорів - Л. Манько, О. Вірину, А. Максимовича, а також за порадою М. Садовського - М. Заньковецьку. Узимку 1883 р. до них долучилися рідні брати М. Садовського Іван, Опанас та сестра Марія Тобілевичі.

Виступи новоутвореного товариства під орудою М. Кропивницького перевершили всі сподівання. Їх виставам аплодували Полтава, Київ, Черкаси, Харків. Успіх трупи М. Кропивницького і його розмови з М. Старицьким під час гастролей у Києві про можливість спільного керівництва театром заохотили останнього до співпраці. Наприкінці травня 1883 р. М. Старицький приїхав до Харкова, де театр завершував гастролі, і зустрівся $з$ М. Кропивницьким. Вони обговорили умови створення та засади діяльності нової трупи. Як антепренер М. Старицький узяв на себе іiі повне матеріальне забезпечення. «До складу трупи входило близько ста осіб (акторів - 32, хору 30, оркестру - 25, решта - адміністративні та допоміжні працівники)» [22, 194]. Виготовлення декорацій, костюмів і реквізиту М. Старицький теж оплачував власним коштом. Для фінансового утримання театру М. Старицький продав один iз своїх маєтків. М. Кропивницький відповідав, зі свого боку, за творчий бік справи, вишкіл акторів і поставу вистав.

Перший виступ такого великого, презентаційного, українського театрального колективу відбувся 15 серпня 1883 р. в Одесі виставою «Наталка Полтавка» I. Котляревського. Осердям нової трупи на чолі $з$ актором і режисером М. Кропивницьким стали рідні брати Тобілевичі: Микола (по сцені Садовський), Іван (Карий), Панас (Саксаган- 
ський), їхня сестра - Марія (Барілотті), а також артистка Ганна Затиркевич. Але найяскравішою зіркою цього колективу видатних акторів стала «краса української сцени», — як писала Старицька-Черняхівська, — геніальна Марія Заньковецька. В історії національної сцени за цими акторами закріпилася назва «корифеї українського театру».

Виступ трупи під дирекцією М. Старицького у Києві з 14 жовтня по 16 листопада 1883 p. розворушив ціле місто. Вистави викликали у глядачів не лише естетичне захоплення, екстаз, бурхливі овації, а й будили і відроджували в їхніх серцях національну свідомість, почуття гордості за українське слово і пісню. Посипалися доноси у Петербург, зокрема, рапорти генерал-губернатора О. Дрентельна, який своїм розпорядженням на довгі роки заборонив українським трупам виступати в Київській губернії. У грудні 1883 р. вдарив мороз жорстких вимог до виконання роз'яснень «Особливої наради», щодо третього пункту Емського указу. Розіслано новий циркуляр усім генерал-губернаторам пильно стежити, щоб не було окремих малоросійських труп, а лише «російсько-малоросійські». У їх репертуарі російські п’єси мали становити половину від українських і виконуватися російською мовою. Ось як намагався зарадити цьому лихові М. Старицький, відтепер директор російсько-малоросійської трупи:

«Петербург, 17 березня [29 березня 1884 р.]

Вельмишановний Петре Петровичу !

Звістки з Петербурга хоча й не зовсім веселі, однак не конче й сумні: гр[аф] Толстой, отримавши декілька доносів з Києва, звернув увагу на малор[осійські] вистави і наказав Головн[ому] упр[авлінню] у справ[ах] друку повідомити адміністративним властям, щоб ті не допускали формування виключно малоросійських труп i стежили, щоби малор[осійські] вистави складали ніяк не більше половини російських, і щоб поруч 3 ними ставились і російські серйозні п’єси, а не самій лише водевілі <..> Ну, з цим становищем наразі примиритись можна, аби лишень не з'їла нас місцева адміністрація, бо ми повністю в ії руках: забагне - i перепон чинити не буде, а не захоче - заборонить - i баста! Отож, вирішив я тепер 3 цими вимогами уладити так: тепер я маю 6 осіб спеціально для російськ[их] комедій, та й наших 8 душ можуть брати участь, - 3 цим персоналом я ставитиму російськ[i] комедії як необхідний додаток до малоросійських спектаклів, яких буде три, чотири щотижня; а два дні ставитиму не російську драму, а оперу чи оперу коміч[ну]. На оперу публіка охочіше піде, та й витрати такі самі, як на драму, а поміж того оперні сили допомагатимуть і малоруській опері і самій навіть драмі... драматичні ж в[елико] російські (п'єси Б. К.) - ні до чого!» [20, 458-459].

Під час гастролей в Одесі 1884 р. на афіші театру М. Старицького вперше на Наддніпрянській Україні з'являється мелодрама І. Гушалевича «Підгіряни» 3 музикою М. Вербицького. Немає жодного сумніву, що поставу «Підгірян» (як оперу на зразок «Наталки Полтавки») запропонував М. Старицькому ввести до репертуару М. Кропивницький, адже він 1875 р. бачив іiї в Галичині на сцені Руського народного театру. Проте у трупі М. Старицького п'єса йшла під назвою «Підгорянє. Карпатскіє рускіє». Саме під такою назвою 1870 р. було подано до дирекції Александрінського театру переклад «Підгірян», як «Подгорянє. Карпатскіє рускіє», здійснений російською мовою єпископом російської православної церкви Володимиром Гречулевичем. Однак п'єса не була рекомендована цензурою до постави. Можливо, М. Старицький, перебуваючи в Петербурзі у справах репертуару свого театру, отримав від міністра внутрішніх справ графа Д. Толстого дозвіл на поставу російського перекладу «Подгорянє. Карпатскіє рускіє» як опери, виконуючи у такий спосіб рішення нового циркуляру. Однак те, що Старицький замінив назву «Подгорянє» на «Підгорянє» дає підставу припустити, що по отриманню дозволу цензури п'єсу було перекладено українською мовою. Ким? Старицьким? Кропивницьким? Достеменно невідомо.

Вперше мелодрама I. Гушалевича під назвою «Підгорянє. Карпатскіє рускіє» поставили в Одесі 1 лютого 1884 р. Як зазначено у «Хронології артистичної діяльності М. Л. Кропивницького» [11, 396-397] Юрія Меженка, iї показали в Одесі двічі, 1 та 18 лютого. Однак у газеті «Одеський вістник» в рубриці «Афіша» читаємо: «Маріїнський театр. У неділю 5 лютого будуть показані: 1) “Підгорянє”, мелодр.[ама] у 3-х д.[іях]. Гушалевича. Беруть участь: панове [М.] Кропивницький, [І.] Карий, [М.] Барілотті, [М.] Гай та інші. 2) “По ревізіі”, етюд в 1 дії, драм[атурга] Кропивницького. Участь беруть панове Кропивницький, Карий, [П.] Саксаганський, [О.] Вірина та ін. 3) "Вона його чекає", вод[евіль] в 1 дії. Участь беруть панове [М.] Журін і [О.] Яблочкіна» [5]. Таким чином, в Одесі «Підгорян» ставили тричі - 1, 5 та 18 лютого.

Марія Заньковецька не брала участі у перших поставах цієї п’єси, однак вважаємо за потрібне подати уривок з рецензії, опублікованої в газеті 
«Одеський вістник» 5-го лютого 1884 р. на виставу 1 лютого. У рецензії названі імена всіх виконавців та висловлена оцінка гри акторів: «<... Поставу мелодрами п. Гушалевича варто подивитись на сцені театру п. Старицького. Порадимо останньому, що дуже витратився на одяг гуцулів, збільшити їх гурт, особливо в третій дії, і запропонувати Фроліні (художник-декоратор - Б. K.) доповнити картину згарища ще й грудою погорілих речей. Серед артистів, насамперед, вирізняється Карий (Іван Тобілевич - Б. К.), що грає роль війта Чопорія. Його розумній грі, без сумніву, допомогла сама роль, значно живіша, аніж, наприклад, роль Трохима, старої людини напротивагу Чопорію, яка втілює собою риси доброчесності, що, врешті-решт, в кінці перемагають. Роль Трохима виконав незамінний там, де потрібно вагомо і виразно окреслити тип - п. Кропивницький. Публіка менше аплодувала йому тому, що роль Трохима не особливо цікава. Не міг не сподобатись глядачам спів п. Грицая [Степан], а Саксаганський [Присяжний Василь], хоча й знову в наслідок ролі, що не мала ефектних моментів, не викликав у публіки гучних схвалень, але 3 нашого боку було б не справедливо не відзначити його гри. Він добре знав роль і від початку до кінця провів іiі рівно. Видно, що ролі більш-менш спокійні дуже вдаються йому. Вірина (Знахарка) при оригінальному гримі змінила голос і манеру настільки, що в першій дії трудно було їі впізнати. Здається, що в другій дії, коли вона довідується, що війт ії одурив, потрібно більше жвавості, енергії. Надзвичайно цікавою була Барілотті (Ганна), хоча слід було б більше загримуватися, щоб виглядати старшою, а в третій дії, за допомогою того ж гриму, надати обличчю більшої втоми. Пані Гай виконувала дуже трудну роль (Ольга), і виконувала краще, аніж можна було очікувати. Третя дія була особливо ризикованою. Потрібно було показати достеменний перехід зі стану божевілля до повної свідомості, і якщо пані Гай не достатньо підкреслювала цей момент переходу, коли впізнає Степана, але іiі загальний вигляд і мова до цього моменту цілковито відповідали фізично слабкій, втратившій розум, Ользі. Що стосується пані Затиркевич [дружина Чопорія], то про неї нема що казати: варто було їй тільки гримнути на Чопорія, як у залі чулися з різних боків голоси схвалення. Останнє слово до режисера. До цього часу малоросійська трупа користувалася пошанівком публіки за те, що антракти завжди були не вельми довгі. Чи не можете Ви змінити у публіки вдячність на нарікання? 3-к.» [5]
Таким жартівливим побажанням критик «3-к.» завершив свою рецензію. Роль Ольги Марія Заньковецька, за тими матеріалами, котрі ми віднайшли, вперше виконувала у Воронежі, де показували «Підгорян» 23 липня 1884 р. У брошурі В. А. Кендзерського «Малоруський театр М. П.Старицького в Вороніжі (Від 8 по 26 липня 1884 р.)» подано перелік дійових осіб вистави «Підгорянє» та їх виконавців: «23 (липня) Підгорянє (Карпатськіє рускіє), мелодрама в 3-ох діях авт[орства] І. Гушалевича, бенефіс (В. С. Грицая). Дійові особи: Трохим - [М.] Кропивницький; Ганна, його дружина - [М.] Барілотті-Садовська; Ольга, їхня дочка - [M.] Заньковецька; Степан [В.] Грицай; Чопорій, війт - [П.] Саксаганський; Тетяна, його дружина - [O.] Вірина; Василь, присяжний — [Ю.] Касиненко; Знахарка — [?] Діллер» $[6,18]$. У цій же брошурі подано рецензію на виставу 3 газети «Вороніжский телеграф» за 29 липня № 85: «Якщо дотепер ми висловлювали подяку трупі п. Старицького за відтворення перед нами історично правдивих козаків і не менш реальних малоросів, то за спектакль 23 липня ми повинні висловити йому глибоку вдячність, так як у п’єсі “Підгорянє” нам показали не тільки малороса, а взагалі слов’янина, у всій його привабливій простоті. Трудно (та й не до місця) визначати, що саме робить цю п’єсу для публіки неймовірно симпатичною, але, виходячи 3 вражень, вона залишає глибокий слід в душі кожного, хто вникнув в її суть. Не знаю напевно, - як приймають цю п’єсу в інших місцях (хоча не без підстави вважаю, що добре); але, на мою скромну думку, вона $\epsilon$ найкращою із всього того гарного, що у нас показала трупа п. Старицького. Та й публіка, здається, так само сприйняла цю виставу: на їі бажання і на одностайну вимогу 3 усіх 12 вокальних номерів - одинадцять були повторені» [16, 33-34]. В. Кендзерський у своїй брошурі подав, окрім дійових осіб п'єси та їх виконавців, також перелік музичних номерів, виконаних у виставі:

«1. Чого лози нахилились (соло).

2. У полі пшениченька розвилась (соло).

3. По річці густі тумани (дует).

4. Ваша хата $з$ огородом (соло).

5. Ми в луг підем (хор).

6. Моя мила, чорнобрива (соло).

7. Поле моє, поле (соло).

8. Скінчиться день і тяжкий труд (хор).

9. Чи ми тебе, доню (соло).

10. Легше рибці оддихати (соло).

11. Плила рибка золотая (хор).

12. Хто з нами, ми за ним (хор)» $[6,19]$. 
3 поданих В. Кендзерським вокальних номерів, як зазначив автор рецензії Пйотр 3., одинадцять - актори повторювали на біс. Зацитуємо оцінку, яку дав рецензент грі акторів: «Що стосується виконання, то воно було бездоганним у грі всіх артистів. П.[ан] Кропивницький з ролі Трохима створив для глядачів надзвичайно симпатичний тип. П.[ані] Заньковецька в ролі Ольги виділялась грою без шаржування і штучності, а найголовніше - задушевністю, сердечністю виконання. Треба відзначити й те, що п. Заньковецька у сцені стану хвороби, що відступила, коли вона впізнає Степана (сцені безмежної радості!) була набагато кращою, аніж у сцені хвороби й існування в ній. $<\ldots>$ В останніх спектаклях, в середу 25 , в четвер 26 липня, в театрі-цирку трупа п. Старицького удостойлась таких овацій, яких Вороніж не забуде. $<$...> Завіса піднімалася мінімум 20 разів. Публіка почала розходитись тільки тоді, коли в театрі загасили світло. У цьому виявилась загальна думка, i, без сумніву, правдива оцінка артистів» $[16,34]$.

Говорячи про вокальний голос М. Заньковецької, В. Кендзерський у брошурі зазначив: «Заньковецька - мецо-сопрано. Голос невеликий, але правильно поставлений, надзвичайно приємний $\mathrm{i}$ глибоко симпатичний. Виконання усіх без винятку музичних п'єс надзвичайно майстерне, при цім народне і цілковито оригінальне» [6, 44-45].

Загалом у сезоні 1884 р. «Підгоряни» йшли 9 разів: тричі в Одесі - 15 та 18 лютого, Воронежі - 23 липня, у Харкові $-8,26$ вересня та 8 листопада, відтак знову в Одесі - 16 та 30 грудня.

Після завершення одеських гастролей 4 лютого 1885 р. М. Кропивницький виходить із трупи М. Старицького і створює власне театральне товариство, до якого прийняті актори з його попередньої трупи, зокрема: М. Заньковецька, М. Садовський, П. Саксаганський, Г. Затиркевич. Трупа Кропивницького розпочала театральний сезон у березні в Слисаветграді, а вже 9 червня 1885 р. у Миколаєві на афіші з'являється мелодрама «Підгорянє», а відтак іiї грають і в Харкові 21 листопада. У цих виставах, напевно, виступала Марія Заньковецька.

Під час знаменитих гастролей трупи М. Кропивницького у Петербурзі від 11 листопада 1886 р. по 15 лютого 1887 р., які організувала йому антрепренер В. Лінська-Наметті, грали і виставу «Підгірянє». Про це довідуємося з петербурзької газети «Театральный мирок» (10 січня 1887 р.): «Найближчою новинкою малоросійської сцени буде оперета "Підгоряне", музика до якої належить Вербицькому. Сюжет цієї 3-актної п’єси, лібрето до якої написав Гушалевич, узято 3 галицько-руського життя. Більшість арій в них запозичено з галицьких народних мотивів» [24, 9]. Однак у «Хронології артистичної діяльності М. Л. Кропивницького», укладеній Ю. Меженком, не подано дати постави «Підгорян» у переліку репертуару, з яким трупа виступала в Петербурзі.

3 історії українського театру знаємо, що у той самий час коли трупа М. Кропивницького грала в Петербурзі, у Москві гастролювала трупа М. Старицького від 7 грудня 1886 р. по 20 квітня 1887 р. $[12,451]$. У рубриці «Московскіє весті» (газета «Театральный мирок») читаємо: «Поставлена вперше 18 січня малоросійська мелодрама "Підгорянє” зібрала повний аншлаг; для багатьох охочих потрапити в театр не вистачило навіть місця. Вся музика, написана до цієї п’єси, носить досить дивний відтінок, а саме - церковний. Єдиним винятком можна вважати романс Степана в 3 кар. [тині], написаний в італійській манері і прекрасно виконаний п. [В.] Грицаєм. Цей церковний колорит легко зрозуміти, якщо взяти до уваги, що більшість галицьких авторів і композиторів, у зв'язку 3 наслідками Люблінської унії, є духовними особами. Роль героїні п'єси Ольги, яку виконала пані [Є.] Боярська, тією чи іншою мірою є варіантом до ролей двох Олен в п'єсах “Глитай або ж павук” і “Не ходи Грицю...”; на початках пристрасне кохання, потім розлука і врешті або божевілля (обов'язково!), або типова радість. У “Підгорянах" є маленька відмінність від трафаретної манери: Ольга, перебуваючи у стані божевілля до кінця п’єси, у фіналі від радості стає здоровою. Роль зловмисника війта Чопорія дуже типово передав пан [Ю.] Касиненко, викликаючи при всій несимпатичності виконуваної ролі гучні аплодисменти. Пан [I.] Бурлак просто і задушевно виконав роль добропорядного присяжного Василя так само, як пан [К.] Ванченко (батько Ольги) був вельми і вельми задовільним. Обдарована О. І. Вірина виступила у цій п'єсі, що досить дивно, в незначній ролі дружини війта, яку виконала 3 властивою їй простотою і привабливою веселістю» $[13,9-10]$.

Після успішних гастролей трупи М. Кропивницького у Петербурзі, широко висвітлених як в українській, так і в російській театральній літеpaтурі, Марко Лукич покидає створене ним Товариство. Проте 1889 р. збирає нову трупу, більшість акторів якої складають молоді обдаровані аматори: О. Суслова, Ф. Левицький, Є. Зарницька, У. Суслова, до акторського вишколу яких він доклав чимало зусиль. Театральний сезон трупа розпочала в Слисаветграді 15 січня 1889 р. Саме 
для цієї нової трупи М. Кропивницький здійснив переклад (перерібку) українською мовою п'єси I. Гушалевича «Підгоряни» — скоротивши текст вокальних творів та в деяких діалогах. Зробив це у Харкові в березні 1890 р., а вже у травні того ж року отримав цензурний дозвіл на поставу. (Рукопис перекладу зберігається у Театральній бібліотеці Санкт-Петербурга. Шифр 53067).

Прем’єра «Підгорян» у перекладі М. Кропивницького українською мовою відбулася 17 лютого 1891 р. в Ростові-на-Дону.

У фондах Державного музею театрального, музичного та кіномистецтва України зберігається лист артистки Єфросинії Зарницької (Азгуріді) до матері, написаний 6 лютого 1891 р. $з$ Ростова-на-Дону. Із листа довідуємось про хід генеральних репетицій вистави «Підгоряни»: «Днями йтиме нова п'єса "Підгоряни", можете уявити моє хвилювання, роль найтрудніша зі всього репертуару - на сцені жахливі переходи - від безумства до свідомості, істерика і таке інше. Одне слово, тепер йде генеральна муштра, так як Марко [Кропивницький] хоче поставити ії на мій бенефіс, і я хвилююся удвічі більше <...> Дехто переказував, що мене вважають у майбутньому другою Заньковецькою» [8, арк. 1]. Про виставу 17 лютого газета «Донская пчела» помістила коротку замітку-рецензію у № 14 за 21 лютого 1891 р.: «П’єса "Підгіряни", поставлена вперше 17 лютого, мала великий успіх. Роль Трохима пан Кропивницький передав у вищій мірі мистецьки. Арія "Поле моє, поле" була виконана з таким натхненням, що справила сильне враження. Пан Левицький грав роль зловмисника Чопорія і виявив багато обдуманості. Його Чопорій вийшов живим персонажем без найменшого шаржування. У деяких місцях був настільки переконливим, що публіка аплодувала йому під час гри. Не можемо не дати певної поради панам Магдебурову і Глазуренкові. Вони безумовно прекрасні танцюристи, але їм треба поставити фінальний танець 3 “топірцями”, що більше підходить до гуцульських танців, аніж малоросійський "гопачок", що зовсім не підходить. Ми не могли зрозуміти, що кому заважає: чи “топірці" танцюристам, чи танцюристи “топірцям” » [21]. Ця дещо іронічна замітка відповідає назві газети «Донская пчела». Можемо сказати до слова, що дописувач з категорії «трутнів» не помітив «трудівниць бджілок» в особі Зарницької - виконавиці ролі Олі та першорядної артистки Затиркевич у ролі дружини сільського старости. За «Хронологією творчості М. Кропивницького» в Ростові п’єсу ставили двічі. - 17 лютого і 1 березня. Проте в галицькому альманасі «Зоря» за 1891 р. знаходимо інформацію: «Товариство під управою Марка Кропивницького $<\ldots>3$ творів галицьких авторів виставило се товариство в Ростові-на-Дону перший раз "Підгіряни", - а відтак повторило їх три рази при повних зборах» $[10,219]$. Якщо вперше в Ростові показано «Підгорян» 17 лютого і 1 березня, то $з$ огляду на інформацію в «Зорі» їх ставили ще двічі «при повних зборах».

Про виступ Є. Зарницької в ролі Ольги у Новочеркаську 23 травня знаходимо коротку газетну замітку, яка зберігається у її альбомі: «24 мая бенефіс пані Зарницької йшла мелодрама "Підгоряне”. Прекрасну роль Ольги провела бенефіціантка 3 таким глибоким почуттям, що глядачам трудно було втриматись від переживань. Артистці піднесли розкішний букет троянд, перев'язаний широкими стрічками рожевого і яскраво багряного кольору» [1, арк. 31].

Після Ростова трупа переїхала до Таганрога, де 17 червня 1891 р. показували «Підгорян», в Одесі їх грали 27 жовтня, а 3 листопада до кінця грудня трупа Кропивницького перебувала на гастролях у Петербурзі.

Виставу «Підгоряни» Кропивницький показав у Петербурзі 1891 р. двічі (29 листопада і 9 грудня). В Альбомі рецензій Єфросинії Зарницької знаходимо відгук на виставу в газеті «Петербурзький листок»: «Поставлена на сцені Кононовського театру драма "Подгорянє" перероблена з русинського, але вона також, як і більшість його (Кропивницького - Б. К.) творів, нагадує нам радше оперу, тому, що в ній музичні і вокальні елементи у більшості переважають. Ця п'єса у гарному декораційному оформлені була виконана паном Кропивницьким i його акторами з рідкісним натхненням і справила дуже хороше враження на глядачів. <..> 3-поміж виконавців пальма першості повністю належить пані Зарницькій (у ролі Ольги). Більш прекрасну Ольгу трудно собі уявити. Своєю симпатичною грою і чарівним співом вона заворожила глядачів. Пані Затиркевич (дружина сільського старости) і пані Суслова (мати Ольги) мали великий успіх. Добрим у ролі Степана був і п. Арцимович, володіючи чудовим тенором, одухотворено виконав свою партію. Дуже типовим в ролі сільського старости був п. Левицький, виконуючи свою роль розумно і жваво. Що стосується самого п. Кропивницького (батько Ольги), то його усім відома зразкова і талановита гра стоїть понад всіма шаблонами рецензійних відгуків. П'єса мала безсумнівний успіх, автора і артистів викликали безліч разів» [2, арк. 36]. 
У сезоні 1892 р. трупа Кропивницького виставу «Підгоряни» грала 8 разів. 3 них один раз 13 лютого 1892 р. у Варшаві в театрі «Ельдорадо». На цю виставу в газеті «Галицькая Русь» в числах 41 і 421892 р. помістив рецензію Іван Соневицький під криптонімом I.С. Рецензія написана російською мовою. Варто подати 3 неї розлогий уривок: «Дня 13 лютого цього року в театрі "Ельдорадо" русько-малоросійською трупою М. Л. Кропивницького була розіграна в бенефіс артиста Ф. В. Левицького відома галицько-руська мелодрама “Подгорянє”. На афіші назва п'єси, невідомо чому, "Підгоряни" (чому не галицько-русинське "Подгорянє").

Цікаво було б довідатися, у чому полягає переклад "Подгорян" п. Кропивницького, та ще й 3 "русинської”, бо ми не помітили в тексті жодних відхилень від оригіналу, хоч після прочитання афіші очікували, що п’єса буде понівечена українським "базіканням", неприємним галицько-руському слуху. Невже п. Кропивницький заразився віяннями зловісної “нової ери”? Дивним здається, що для передачі “русинської” п’єси на українській сцені необхідний переклад. П'єса "Подгоряне" була виконана загалом цілком задовільно, але костюми і убоге сценічне оформлення залишають бажати кращого, бо не давали навіть приблизного уявлення про карпатських горян. Найбільш всього глядачам сподобалися дивні мелодії Вербицького, особливо хор “Ми в луг підем всі з косами”, тріо "Не можна серцю двох любити" і соло Трохима (п. Кропивницький): “Поле моє, поле”. Ці номери програми були повторені на вимогу глядачів ще раз. Справила враження сцена божевілля Ольги Трохимівни після повернення з тюрми ії коханого Степана Крипчака (п. Арцимович), майстерно передана пані Зарницькою. Окрім цих виконавців вирізнився також сам бенефіціант (О.Ф. Левицький) в ролі Чопорія, однак придуманий ним костюм - чемерка і конфедератка - зовсім не відповідали костюму карпатських війтів. У фіналі п. Глазуненко чудово виконав гуцульський танець (названий п. Кропивницьким знову ж таки “русинським") зі всією завзятістю карпатського гуцула і також 3 його традиційною спритністю і вмінням володіти “топірцем”. Танець був повторений на бажання публіки. Виставу “Подгоряне”, що відбулася на варшавській сцені завдяки п. Левицькому, треба визнати втішним явищем в малоросійській трупі, репертуар якої складається більшою мірою 3 творів директора трупи п. Кропивницького, артиста безсумнівно талановитого, але при тому занадто плодовитого драматурга, що черпає сюжети для своїх творів виключно зі сфери українського “кохання"

$$
\text { I. C.» }[19,3] \text {. }
$$

Треба сказати, звісно, що немає нічого дивного у критичному погляді Івана Синевицького на виставу та драматургію М. Кропивницького, адже рецензент належав до партії «москвофілів-об' єдинителів», які не визнавали жодної окремої української літератури. 3 Варшави театр переїхав до Вільна, де 22 квітня 1892 р. показали «Підгіряни». Єфросинія Зарницька зберегла у своєму альбомі коротку замітку-рецензію про цю виставу, автор якої заховав своє прізвище під криптонімом «М»: «Не замислуватий ходульний характер п'єси виграє від введення в неї своєрідної і мелодичної музики, деякі номери якої вельми ефектні і красиві. Серед головних виконавців пальму першості як у відношенні вокальному, так і драматичному належить віддати пані Зарицькій. Правдиво і з акторським тактом провів роль Трохима - Кропивницький. Хори були дуже гарні» [3, арк. 34].

Завдяки скрупульозній праці Юрія Меженка «Хронологія артистичної діяльності М.Л.Кропивницького», на яку ми так часто посилаємось, коли йдеться про дати постав «Підгорян», можемо зазначити, що М. Кропивницький під час гастролей у Мінську грав «Підгоряни» 31 травня 1892 р., відтак у Харкові 21 липня та 16 жовтня. Однак не зазначено, що в Слисаветграді (тепер - Кропивницький), виставу «Підгоряни» показували 15 жовтня, про що свідчить афіша, що зберігається в музеї М. Кропивницького. У складі виконавців, крім [М.] Кропивницького [Є.] Зарницької, [Ф.] Левицького, [К.] Левицької, виступали ще [Г.] Борисоглібська, [А.] Маркович, [?] Москаленко, [?] Павленко. Не зазначено також у «Хронології», що «Підгіряни» в сезоні 1894 р. грали в Ніжині, про що свідчить лист М. Кропивницького до Б. Грінченка від 9 грудня 1894 року: «< .. > Сьогодні придибав до мене Гаврилей, дав йому десять квитків, щоб привів вертіївцівських хлопців і дівчат на "Підгоряне".

Ніжин, 1894 р.» [9, 434-435].

До показу «Підгірян» М. Кропивницький звертався ще 9 разів - востаннє в Одесі 11 січня $1900 \mathrm{p}$.

Чи ставили у другій половині XIX ст. ще якісь українські трупи мелодраму I. Гушалевича, невідомо. Щоправда, зберігся лист Івана Тобілевича, написаний 22 липня 1890 р. до Лукича-Левицького - редактора галицького журналу «Зоря»: «Коли Ваша ласка, то вишліть мені в Севастополь “Підгоряни” і музику до цієї п’єси - те й друге 
надруковане. Крім того, просю Вас вислать такі п'єси 3 народного побуту, котрі у Вас в Галичині мають найбільший поспіх: може б ми як-небудь хитро-мудро добились постановки їх у нас» $[14$, 79]. Іван Тобілевич (Карпенко-Карий) цікавився «Підгорянами», вочевидь, для репертуару трупи, яку очолював його брат Панас Саксаганський. На той час М. Кропивницький уже переклав «Підгорян» українською мовою і одержав дозвіл цензури на їх поставу.

Серед театрознавців побутує думка, що М. Кропивницький здійснив вперше переклад «Підгорян» для трупи М. Старицького 1884 p. Проте достеменно знаємо, що «Підгорян» ставили у трупі Старицького під назвою «Подгоряне (Карпатськиє рускіє)»: саме так В. Гречулевич назвав свій переклад російською мовою, який не був рекомендований до постави на російській сцені. Хоч як дивно, але цей російський переклад «Подгорян» був заборонений царською цензурою і вдруге, одразу після того, як трупа Кропивницького показала їх 10 січня 1987 р. в Петербурзі. На рукописі російського перекладу під вердиктом цензора Єгора Кайзера фон Нількенгейма: «До постави признати не бажаною» стоїть дата 15 січня 1887 р. (Санкт-Петербурзька театральна бібліотека [Шифр 44736]). Що ж такого крамольного було в п'єсі І. Гречулевича, що російська цензура, дозволивши грати «Подгорян» малоросійським трупам, двічі забороняла їх до постави на російській сцені? Гадаємо, що відповідь на поставлене питання дає початок рецензії на першу виставу «Підгорян» трупи Старицького в Одесі 1 лютого 1884 p.:

\section{«Виступ драматичної трупи М. П. Старицького “Подгорянс (Карпатскіс рускіс)" мелодрама в 3-х діях І. Гушалевича, 1 лютого}

Якщо б ми забажали детально зупинитися на вперше поставленій у нас мелодрамі “Подгорянє”, розглянути іiі достоїнства і недоліки, то ми з бажанням бути об'єктивними зобов'язані були б не менш детально говорити про драматургію в Галичині, іiі цілі і завдання і т.д. тому, що звідси витікають усі достоїнства і недоліки драми "Подгорянє". Залишаючи тому збоку аналіз драми, ми обмежимось відповіддю на питання: чим цікавою $є$ ця мелодрама для глядачів театру пана Старицького? Останній, як ми вже мали честь писати, прекрасно розуміє, яке значення має оформлення п'єси, а режисер його трупи пан Кропивницький не поступається антрепренерові в розумінні того, як вдале ви- конання акторів згладжує іноді найбільші недоліки п'єси. < . .> Найперше, глядач знайомиться, хоча б частково, з типами людей, що різняться від наших право- і лівобережних українців. Перед нами прикарпатське село в горах, мистецьки відтворене декоратором. У цьому селі й відбувається дія. Ви чуєте чисту галицьку малоросійську мову, пересипану досить помітними діалектними особливостями; чуєте пісні, музика яких хоча й нагадує нашу українську, але частково наповнена такими особливостями, що ви мимоволі переноситесь в цілковито інший світ. Ви бачите перед собою гурт селян, людей теж не цілком нам знайомих; загальний тип їх, вбрання, танці, - все для нас новинка. Врешті, в цьому селі і відносини цілком відмінні від тих, 3 якими ми привикли зустрічатися в драмах і комедіях наших письменників; війт трішки нагадує нам нашого старосту, присяжний — також не близький наш знайомець, а знахарка, хоч вона обов'язковий персонаж і нашого села, але так виразно відрізняється від нашої знахарки, значно втративши риси злої відьми, що і цей тип представляє собою для нас цікавість. Додайте до цього звичаї, з якими ви частково знайомитесь, стан розвитку народу і т.д., то й ви погодитесь, що мелодраму пана Гушалевича варто подивитись в поставі на сцені пана Старицького» [5].

Показати зі сцени життя українського галицького села в Австро-Угорській імперії: його звичаї, характери, активність громади без сумніву було б разючим контрастом по відношенню до життя селян у Російській імперії. Саме цей контраст викликав заборону російської цензури щодо «Підгорян».

Практично у всіх, наведених нами рецензіях, відзначено рецензентами гру акторів і музику М. Вербицького - як виняткове і оригінальне явище.

У рік двохсотліття від дня народження М. Вербицького жодна 3 театральних п'єс, до яких він писав музику i зокрема, до найвагомішої - «Підгірян», не удостоїлись побачити світло сцени. Подиву гідне, що ні один український режисер ні старшого, ні молодшого покоління не виявив бажання прочитати цю музичну драму мовою сучасного театру, дати нове життя театральній музиці М. Вербицького, якій аплодували в царській Росії і в бездержавній Україні. Сподіваємось, що в державній Україні ця стаття написана не марно.

\section{Література та джерела}

1. Альбом рецензій Єфросинії Зарницької //Державний архів театрального, музичного, кіно-мистецтва України. - 
Фонд Р. - Інв. номер 32. - Арк. 31 (переклад 3 рос. автора статті).

2. Альбом рецензій Єфросинії Зарницької //Державний архів театрального, музичного, кіно-мистецтва України. Фонд Р. - Інв. номер 48. - Арк. 36. «Петербурзький листок» 1891 г. - 1 декабря - № 329 (переклад 3 рос. автора статті).

3. Вилєнский вестник. - 1892. - 24 апреля. - № 87 // Державний музей театрального, музичного та кіно-мистецтва України // Альбом Є. Зарицької. — Фонд 5007. № 44. - Арк. 34.

4. Возняк М. В єднанні з народом Наддніпрянщини / Михайло Возняк // Марко Лукич Кропивницький : Збірник статей, спогадів, матеріалів. - Київ : Мистецтво, 1955. - С. $144-169$.

5. 3-к. Виступление драматической трупы М.П. Старицького «Пидгорянє (Карпатскиє русскиє)», мелодрама в 3-х действиях И. Гушалевича, 1 февраля // Одесский вестник. - 1884. - 5 февраль. - № 29.

6. Кендзерський В. А. «Малорусский театръ» М. П. Старицкаго въ Воронеже (Съ 8 по 26 Іюля 1884 года). С. Петербургъ. - 1885. - С. 18 (переклад з рос. автора статті).

7. Кропивницький М. Л. Автобіографія (за 65 літ) / М. Л. Кропивницький // Марко Лукич Кропивницький : Збірник статей, спогадів, матеріалів. - Київ : Мистецтво, 1955. - 530 c

8. Лист Єфросинії Зарницької до матері // Державний архів театрального, музичного, кіно-мистецтва України. Фонд Р. - Інв. номер 1552. - Арк. 1 (переклад 3 рос. автора статті).

9. Лист М. Кропивницького до Б. Д. Грінченка №88. - 9 грудня 1894 р. // Марко Кропивницький : Твори в шести томах. - К. : Держлітвидав, 1958. - Т. 6. - С. 434-435.

10. Лукич В. Перегляд наших товаришів драматичних / Василь Лукич // Зоря. Рубрика «Театр». — 1891. — № 11. — C. 219.

11. Меженко Ю.Хронологія артистичної діяльності М. Л. Кропивницького : матеріали до біографії / Ю.Меженко // Марко Лукич Кропивницький : Збірник статей, спогадів і матеріалів. - К. : Мистецтво, 1955. - С. 396397.

12. Меженко Ю. Матеріали до історії українського дореволюційного театру. Розділ 1. Облік українських труп / Юрій Меженко // Записки Наукового товариства імені Шевченка. - Том. CCLIV. - Праці театрознавчої коміciï. - Львів, 2007. - С. 451.

13. Московские вести // Театральный мирок. - СПб. 1887. - 24 января. - С. 9-10 (переклад 3 рос. автора статті).

14. Невідомий Іван Тобілевич (Карпенко-Карий : листи, п'єси / упор., вст. стаття С. Бронзи. - Кіровоград, 2012. $576 \mathrm{c}$.

15. Осипович К. Марко Лукич Кропивницький / К. Осипович // Новий час. - 1935. - Вересень - Ч. 211-215 ; Жовтень. - Ч. 231-239.

16. Петр 3. Подгоряне. «Воронежский телеграф». - 29 июля. № 85 // Кендзерський В. А. «Малорусский театръ» М. П. Старицкаго въ Воронеже (Съ 8 по 26 Іюля 1884 года). С. Петербургъ. - 1885. - С. 33-34 (переклад з рос. автора статті).

17. Пилипчук Р. Золота доба українського театру (80-90рp.)/ Ростислав Пилипчук // Історія української культури : у 5-ти томах. - Т. 4. - Кн. 2 «Українська культура другої половини XIX ст.» / Гол. ред. Скрипник Г. А. - Київ : Наукова думка, 2005. - 1293 с.

18. Соневицький І. Рубрика «Хроніки». Підгоряни в Варшаві // Галицька Русь, 1892. - 21 февраля (4 марта), № 41; 42. - C. 3.
19. Старицький М. Твори : в 6 томах / Михайло Старицький // Упор. Л. С. Дем'янівська. - К. : Вид-во художньої літератури «Дніпро», 1990. - Т. 6 : Оповідання, статті, автобіографічні твори, вибрані листи. - 831 с. (Переклад 3 рос. Ніни Бічуї).

20. Театр Любова //Донская пчела. - № 14. - 21 февраля 1891. (Переклад з рос. автора статті).

21. Український драматичний театр. Нариси у двох томах / Відпов. ред. М. Т. Рильський. - К. : Наукова думка, 1967. - Т. І. Дожовтневий період. - 520 с.

22. Чарнецький С. Нариси історії українського театру в Галичині / Степан Чарнецький // Історія українського театру в Галичині : нариси, статті, матеріали, світлини. - Львів : Літопис, 2014. - 584 с

23. Частныя сцены. Малорусский театръ // Театральный мирок. - СПб. - 1887. - 10 января. - С. 9. (Переклад 3 рос. автора статті)

\section{References}

1. Albom retsenzii Yefrosynii Zarnytskoi //Derzhavnyi arkhiv teatralnoho, muzychnoho, kino-mystetstva Ukrainy. — Fond R. - Inv. nomer 32. - Ark. 31 (pereklad z ros. avtora statti).

2. Albom retsenzii Yefrosynii Zarnytskoi //Derzhavnyi arkhiv teatralnoho, muzychnoho, kino-mystetstva Ukrainy. - Fond R. - Inv. nomer 48. - Ark. 36. «Peterburzkyi lystok» 1891 h. - 1 dekabria - № 329 (pereklad z ros. avtora statti).

3. Vylienskyi vestnyk. - 1892. - 24 aprelia. - № 87 // Derzhavnyi muzei teatralnoho, muzychnoho ta kinomystetstva Ukrainy // Albom Ye. Zarytskoi. — Fond 5007. № 44. - Ark. 34 .

4. Vozniak M. V yednanni z narodom Naddniprianshchyny / Mykhailo Vozniak // Marko Lukych Kropyvnytskyi : Zbirnyk statei, spohadiv, materialiv. — Kyiv : Mystetstvo, 1955. - S. 144-169.

5. Z-k. Vistuplenie dramaticheskoy trupyi M.P. Staritskogo «PidgoryanE (KarpatskiE russkiE)», melodrama v 3-h deystviyah I. Gushalevicha, 1 fevralya // Odesskiy vestnik. 1884. - 5 fevral. — \# 29.

6. Kendzerskiy, V. A. «Malorusskiy teatr'» M. P. Staritskago v' Voronezhe (S' 8 po 26 Iyulya 1884 goda). - S. Peterburg'. 1885. - S. 18.

7. Kropyvnytskyi, M.L.Avtobiohrafiia (za 65 lit) / M.L. Kropyvnytskyi // Marko Lukych Kropyvnytskyi : Zbirnyk statei, spohadiv, materialiv. - Kyiv : Mystetstvo, 1955. - $530 \mathrm{~s}$.

8. Lyst Yefrosynii Zarnytskoi do materi // Derzhavnyi arkhiv teatralnoho, muzychnoho, kino-mystetstva Ukrainy. - Fond R. - Inv. nomer 1552. - Ark. 1 (pereklad z ros. avtora statti).

9. Lyst M. Kropyvnytskoho do B. D. Hrinchenka №88. - 9 hrudnia 1894 r. // Marko Kropyvnytskyi. Tvory v shesty tomakh. - K. : Derzhlitvydav, 1958. - T. 6. - S. 434-435.

10. Lukych, V.Perehliad nashykh tovaryshiv dramatychnykh / Vasyl Lukych // Zoria. Rubryka «Teatr». - 1891. № 11. - S. 219.

11. Mezhenko, Yu. Khronolohiia artystychnoi diialnosti M.L.Kropyvnytskoho : materialy do biohrafii / Yu.Mezhenko // Marko Lukych Kropyvnytskyi : Zbirnyk statei, spohadiv i materialiv. - K. : Mystetstvo, 1955. — S. 396-397.

12. Mezhenko, Yu. Materialy do istorii ukrainskoho dorevoliutsiinoho teatru. Rozdil 1. Oblik ukrainskykh trup / Yurii Mezhenko // Zapysky Naukovoho tovarystva imeni Shevchenka. - Tom. SSLIV. Pratsi teatroznavchoi komisii. - Lviv, 2007. S. 451.

13. Московские вести // Театральный мирок. - СПб. - 1887. 24 января. - C. 9-10 (pereklad z ros. avtora statti) 
14. Nevidomyi Ivan Tobilevych (Karpenko-Karyi : lysty, piesy / upor., vst. stattia S. Bronza. - Kirovohrad, 2012. - 576 s.

15. Osypovych, K. Marko Lukych Kropyvnytskyi / K. Osypovych // Novyi chas. - 1935. - Veresen - Ch. 211-215; Zhovten. - Ch. 231-239.

16. Petr, Z. Podgoryane. "Voronezhskiy telegraf». - 29 iyulya. \# 85 // Kendzerskiy V. A. «Malorusskiy teatr'» M. P.Staritskago v Voronezhe (S' 8 po 26 Iyulya 1884 goda). S. Peterburg. - 1885. - S. 33-34 (pereklad z ros. avtora statti).

17. Pylypchuk, R.Zolota doba ukrainskoho teatru (80-90 rr.) / Rostyslav Pylypchuk // Istoriia ukrainskoi kultury : u 5-ty tomakh. - T. 4. - Kn. 2 «Ukrainska kultura druhoi polovyny KhIKh st.» / Hol. red. Skrypnyk H. A. - Kyiv : Naukova dumka, 2005. - $1293 \mathrm{~s}$.

18. Sonevytskyi, I. Rubryka «Khroniky». Pidhoriany v Varshavi // Halytska Rus, 1892. — 21 fevralia (4 marta), № 41; 42. — S. 3.
19. Starytskyi, M. Tvory : v 6 tomakh / Mykhailo Starytskyi // Upor. L.S. Demianivska. - K. : Vyd-vo khudozhnoi literatury «Dnipro», 1990. - T. 6 : Opovidannia, statti, avtobiohrafichni tvory, vybrani lysty. - 831 s. (Pereklad z ros. Niny Bichui).

20. Teatr Lyubova //Donskaya pchela. — \# 14. - 21 fevralya 1891. (Pereklad z ros. avtora stattI).

21. Ukrainskyi dramatychnyi teatr. Narysy u dvokh tomakh / Vidpov. red. M. T. Rylskyi. - K. : Naukova dumka, 1967. T. I. Dozhovtnevyi period. $-520 \mathrm{~s}$.

22. Charnetskyi, S. Narysy istorii ukrainskoho teatru v Halychyni / Stepan Charnetskyi // Istoriia ukrainskoho teatru v Halychyni : narysy, statti, materialy, svitlyny. - Lviv : Litopys, 2014. - $584 \mathrm{~s}$.

23. Chastnyiya stsenyi. Malorusskiy teatr // Teatralnyiy mirok. SPb. - 1887. - 10 yanvarya. - S. 9. (Pereklad z ros. avtora statti). 